\title{
Memahami Mazmur 23:5a dari Sudut Pandang Eskatologi Pentakosta Klasik
}

\author{
Silwanus Gabriel
}

Pendahuluan

Mazmur 23 merupakan salah satu mazmur dengan imageri yang figuratif tentang keberadaan Tuhan sebagai gembala yang baik. Gambaran keberadaan Tuhan sebagai gembala yang baik tersebut mendatangkan kebahagiaan atau keberkatan bagi pemazmur. Apabila menelusuri keenam ayat tersebut dengan saksama maka pada ayat 5a menyiratkan adanya 'konsep berkat eskatologis' bagi pemazmur yang mengakui dan menyakini penggembalaan Tuhan dalam hidupnya. Adanya sudut pandang eskatologis pada Mazmur 23:5a terlihat dari pernyataannya yang berbunyi "Engkau menyediakan hidangan bagiku di hadapan lawanku, Engkau mengurapi aku dengan minyak,.." Pernyataan menyediakan hidangan dan mengurapi dengan dengan minyak menunjukkan konsep eskatologis yang dapat dibaca dari sudut pandang eskatologi Pentakosta klasik.

Berkenaan dengan tujuan tersebut di atas maka tulisan yang bersifat refleksif ini ${ }^{145}$ hendak menggambarkan hubungan antara penggunaan imageri perjamuan makan di dalam Perjanjian Lama dan Perjanjian Baru dengan harapan eskatologis Pentakosta klasik. Hasil dari penggambaran imageri tersebut kemudian menjadi plot untuk membaca Mazmur 23:5a dari sudut Pentakosta klasik. Hasil akhir yang diharapkan adalah, setiap pembaca tulisan ini akan termotivasi untuk membaca seluruh Alkitab (bukan hanya kitab Kisah Para Rasul) dari kaca mata pentakosta. Karena pencurahan Roh Kudus yang memberikan kuasa, bertujuan juga untuk membantu semua orang dapat dengan lebih mendalam memahami Firman Tuhan.

145 Tulisan ini tidak dimaksudkan untuk menjadi sebuah tulisan akademis yang begitu rumit, melainkan untuk memberikan satu contoh sederhana tentang cara membaca bagian-bagian Alkitab yang selama ini tidak pernah atau jarang dibaca secara sengaja dari sudut pandang pentakosta. 


\section{Imageri Perjamuan Makan dalam Alkitab}

Para penulis Alkitab menggunakan banyak imageri atau perlambangan dalam tulisan mereka. Sebagai contoh penggunaan imageri gunung batu untuk menunjukkan kekuatan, imageri tongkat membawa arti tuntunan, pertolongan dan bahkan disiplin. Nilai penggunaan imageri-imageri oleh penulis-penulis Alkitab lebih efektif dan akurat karena imageri tidak hanya membawa arti harafiah saja, tetapi ada arti lain di dalamnya. Adanya "arti lain" tersebut berguna untuk berbicara tentang jalan-jalan Tuhan dan kehidupan yang saleh yang seringkali tidak ditemukan dalam kata-kata itu jika hanya diterjemahkan secara harafiah. ${ }^{146}$

${ }^{146}$ Leland Ryken et al., Dictionary of Biblical Imagery, s.v. "Banquet," Electronic Edition (Downers Grove, IL: InterVarsity Press, 2000). 
Secara khusus imageri perjamuan makan, dalam beragam motif, banyak ditemukan di Alkitab baik Perjanjian Lama maupun Perjanjian Baru. Perjamuan makan diadakan untuk menunjukkan keramahtamahan (Kej. 18:5-8147 dan Mat. 22:2-9). Di samping itu, secara insidental perjamuan makan berkaitan dengan kepentingan politik. ${ }^{148}$ Hal ini terlihat pada kisah Ratu Ester menjamu Raja Ahasyweros dan Haman dalam perjamuan makan yang bertujuan untuk kepentingan politik Ester yang ingin melindungi bangsanya. ${ }^{149}$

Ketika kemenangan dalam peperangan diperoleh, pihak yang menang akan mengadakan perjamuan makan untuk merayakan kemenangan itu. ${ }^{150}$ Kejadian 14:1718 mencatat tentang kemenangan Abram dan atas kemenangan itulah Melkisedek datang menghampirinya membawa anggur dan roti. Maksud utama Melkisedek bukanlah hanya makan bersama dengan Abram, tetapi dia ingin memberkati Abram atas kemenangannya. Maksud ini jelas terlihat dengan kalimat "setelah Abram kembali dari mengalahkan Kedorlaomer dan raja-raja yang bersama dengan dia." Penulis cerita ini dapat saja mengatakan "setelah Abram kembali dari peperangan," namun justru penulis memilih menggunakan kata mengalahkan untuk menunjukkan bahwa atas alasan itulah Melkisedek datang. Perjamuan makan menjadi wujud dari selebrasi atas kemenangan yang Abram telah raih.

${ }^{147}$ Memang Dictionary of Biblical Imagery, s.v. 'Bangquet' tidak mengkategorikan bagian teks Kej. 18:5-8 sebagai sebuah perjamuan makan dan hanya mencantumkan Mat 22:2-9 sebagai contoh perjamuan makan sebagai wujud keramahtamahan. Akan tetapi bila mengacu pada arti kata banquet yang ada dalam kamus itu, special meal celebrating important events, maka seharusnya tindakan Abraham menjamu tiga orang tamunya dapat ditambahkan di dalamnya. Apabila tindakan Melkisedek yang "hanya" membawa anggur dan roti, termasuk sebagai tindakan banquet maka tindakan Abraham yang menyuruh Sara untuk mengambil tepung yang terbaik, menyuruh bujangnya untuk mengolah daging anak lembu yang baik dan empuk, dan susu dari anak lembu itu, jelaslah termasuk banquet Memang kepada para tamunya Abraham hanya berkata, "biarlah kuambil sepotong roti." Perkataan Abraham itu adalah sebentuk kesopanan yang mengandung arti bahwa semua makanan yang baik yang akan disediakan itu tidak memberatkannya sama sekali.

$$
{ }^{148} \text { Ibid. }
$$

${ }^{149}$ Sebenarnya Ester dapat menyampaikan permohonannya pada Raja Ahasyweros ketika dia menghadap, karena pada saat itu sang Raja sudah mengatakan bahwa apapun yang dimintanya bahkan sampai setengah kerajaanpun akan diberikan, namun Ester tidak melakukannya. Justru dia mengundang Raja dan Haman untuk datang (Est. 5:3-7). Dalam jamuan makan itulah, Ester menyampaikan keinginannya (ay. 7-8). Bush menyebut ini sebagai sebuah bagian dari sebuah rencana yang cerdik dan sangat terencana dalam upayanya mengendalikan keadaan. Fredric Bush W, Word Biblical Commentary: Ruth, Esther, Electronic Edition (Dallas: Word, Incorporated, 2002).

${ }^{150}$ Dictionary of Biblical Imagery, s.v. "Banquet." 
Tidak hanya penggambaran kekinian, imageri perjamuan makan dihubungkan pula dengan pengharapan mesianis. ${ }^{151}$ Yesaya 25:6 yang merupakan pasal dari kitab Yesaya yang menubuatkan tentang akhir zaman mencatat "Tuhan semesta alam akan menyediakan di gunung Sion bagi segala bangsa-bangsa suatu perjamuan dengan masakan yang bergemuk dan bersumsum, anggur yang tua yang disaring endapannya."

Persyaratan untuk berada dalam perjamuan makan mesianis ini jelas disebutkan di ayat-ayat sebelumnya (25:1-5) yaitu kesediaan dari orang-orang yang sebenarnya termasuk kategori lemah, miskin dan berada dalam kesesakan ${ }^{152}$ namun menjadikan Tuhan akan menjadi tempat pengungsian, perlindungan dan naungan bagi mereka. Sebaliknya Dia akan marah pada mereka yang gagah dan sombong (ay.4). ${ }^{153}$ Disinilah terlihat bahwa Yesaya menggunakan ungkapan-ungkapan mesianis ketika mengemas kembali ide tentang ketaatan yang menghasilkan berkat dan ketidaktaatan yang menghasilkan kutuk. Gaya bahasa yang sama tertera pula pada Yesaya 53:2-3 dengan menggunakan ungkapan-ungkapan seperti "tanah kering," "tidak tampan," "dihina dan dihindari," "penuh kesengsaraan dan yang biasa menderita kesakitan," "dihina," dan "tidak masuk hitungan."154

151 Ibid.

152 Kata Sion digunakan untuk menunjuk pada suatu tempat bertahtanya Tuhan, di mana namaNya disebut dan hukum-hukumNya dijalankan. Penggunaan kata ini di paruhan pertama kitab Yesaya sering mengacu pada harapan masa depan, karena pada masa itu baik Israel maupun Yehuda ada dalam dinamika politik yang sangat tinggi dan kondisi moral dan kerohanian yang naik turun. Dengan menggunakan kata 'sion' Yesaya sedang menunjuk pada sebuah keadaan di mana Tuhan bertahta dan memberi keadilan.

Kata 'lemah', 'pengungsi' dan 'miskin' sejajar dengan 'tanah kering', 'tidak tampan', 'dihina dan dihindari', 'penuh kesengsaraan dan yang biasa menderita kesakitan', dan 'tidak masuk hitungan.' Semua ungkapan itu mewakili keadaan tertekan, mengalami ketidakadilan dan ketidakberdayaan. Ungkapan seperti itu di dalam Yesaya 53 digunakan untuk menunjuk pada karakteristik pembebas yang akan datang.

${ }^{153}$ Ayat ini adalah perkembangan dari penjelasan Musa kepada bangsa Israel sebelum mereka masuk ke tanah Kanaan: Jika Israel memilih taat kepada Allah, mereka akan menerima berkat. Sebaliknya, mereka akan menerima kutuk atas ketidaktaatan mereka. Jika mereka tidak mendengar dan tidak melakukan dengan setia semua ketetapan Allah, mereka akan terkutuk (UI. 28:15). Sebaliknya, di ayat 1-14, syarat untuk menerima berkat itu adalah tidak menyimpang ke kanan dan ke kiri dan jika mendengarkan suara Tuhan Allah.

${ }^{154}$ Yesaya 53 jelas memiliki nuansa mesianis. Lindsey mengatakan bahwa pasal ini merupakan salah satu pasal terpenting di PL. Selain itu the messianic significance of the song is the basis of the New Testament quotations and accounts in large part for the extensive debate that surrounds this prophecy. F. Duane Lindsey, "Isaiah's Songs of the Servant Part 4: The Career of the Servant in Isaiah 52:13-53:12," Bibliotheca Sacra 139, no. 556 (1982). Demikian juga dengan pasal 25 ini, meskipun pasal ini tidak masuk dalam bagian kedua di kitab Yesaya, tetapi gaya Bahasa yang dipakainya dapat disamakan dengan pasal-pasal yang bernuansa mesianis di bagian kedua kitab Yesaya. 
Sementara itu, imageri perjamuan makan dalam Perjanjian Baru secara figuratif berkaitan dengan pesta perkawinan. ${ }^{155}$ Sedikitnya terdapat dua teks imageri yang tercatat dalam Injil-injil berkenaan dengan pesta perkawinan. Kedua kisah ini menggunakan jamuan makan dalam hubungannya dengan karya Yesus di dunia. Pertama-tama terdapat dalam Lukas 12:36 yang berbunyi "Dan hendaklah kamu sama seperti orang-orang yang menanti-nantikan tuannya yang pulang dari perkawinan...." Beberapa versi dalam bahasa Inggris menggunakan kata-kata yang berbeda seperti wedding (KJV), wedding feast (NAS) dan banquet (NRS). Lukas pada bagian ini sedang membahas mengenai kesiapan orang-orang yang sedang menanti kedatangan sang tuan, yang dapat datang saja datang sewaktu-waktu. ${ }^{156}$ Sementara dalam Matius 22:4 yang merupakan contoh kedua dari teks di dalam Perjanjian Baru menggambarkan secara figuratif perjamuan makan sebagai sebuah pesta yang pernuh kebahagiaan yang mengundang banyak orang, namun sayang bahwa mereka yang mendapatkan undangan tersebut menolaknya.

Bila memperhatikan konteksnya maka dalam Injil Matius, perumpamaan penolakan undangan menunjukkan penolakan pemimpin-pemimpin agama terhadap Yesus. Sedangkan contoh yang pertama dalam Injil berbicara tentang kedatangan sang tuan yang menuntut kewaspadaan orang-orang yang bekerja kepadanya. Kedua contoh ini tidak menunjukkan hubungan antara perjamuan makan dengan sebuah harapan, tetapi sudah memberikan acuan yang sangat kuat antara imageri perjamuan makan dengan Yesus dan karya-Nya.

Wahyu 19:9 merupakan teks dalam Perjanjian Baru yang menggabungkan tiga bagian di atas yaitu imageri perjamuan makan, karya Yesus dan harapan. Perhatikanlah bunyi dari teks yang dimaksud:

Lalu ia berkata kepadaku: "Tuliskanlah: Berbahagialah mereka yang diundang ke perjamuan kawin Anak Domba." Katanya lagi kepadaku: "Perkataan ini adalah benar, perkataan-perkataan dari Allah.

Bagian pertama dari Wahyu 19:9 menampilkan imageri perjamuan dengan menggunakan frase "perjamuan kawin Anak Domba." Tanner dengan sangat baik

155 Dictionary of Biblical Imagery, s.v. "Banquet."

156 John Nolland, Word Biblical Commentary : Luke 9:21-18:34, World Biblical Commentary 35B (Dallas: Word, Incorporated, n.d.)., 705. Nolland mengatakan bahwa kedatangan tuan ini bukan hanya tiba-tiba melainkan juga untuk membawa judgement, yang terkait erat dengan konsep mesianis. 
menghubungkan imageri perjamuan makan di Wahyu 19:9 ini dengan imageri perjamuan makan seperti tercantum dalam Yesaya 25, Lukas 12 dan Matius 22.

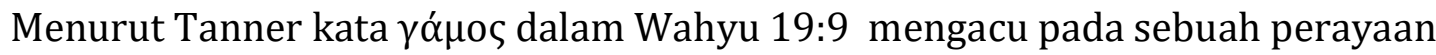
yang menjadi bagian dari sebuah upacara pernikahan. Dalam pesta tersebut terdapat beberapa bagian penting yang perlu ada dalam sebuah perjamuan kawin. Bagianbagian penting yang dimaksud misalnya adanya minuman bila berkaitan dengan perjamuan kawain di Kana; selain itu setiap orang yang diundang juga harus mengenakan pakaian pesta seperti yang dicatat dalam Mat. 22:11-12; Setelah pesta selesai, mempelai laki-laki akan pulang, dan waktu kepulangannya tidak diketahui oleh hamba-hambanya (Luk. 12). Selain itu, akan ada tamu yang diundang khusus untuk menghadiri pesta ini (Mat. 22:10).

Di bagian selanjutnya Tanner mengatakan bahwa Yes. 25 adalah paralel dari Wah. 19.157 Tanner menjelaskan bahwa, khususnya Yesaya 25:6 dan 9 lah yang tegas berkaitan. Di ayat 6 dirincikan tentang pesta perkawinan yang dalam Wahyu 19:7 disebut sebagai perkawinan anak Domba. Sedangkan di Yesaya 25:9 disebutkan tentang 'sukacita' dan 'sorak sorai' yang dialami oleh orang-orang yang hadir dalam perjamuan itu. Kedua kata itu 'sukacita' dan 'sorak sorai' juga digunakan dalam Wahyu 19:7. Menarik untuk diperhatikan, kata untuk bersoraksorai di Yesaya 25:6 dalam LXX sama dengan kata yang digunakan dalam Wahyu 19:7.

Bagian kedua penjelasan lain dari Tanner tentang Wahyu 19:9 ini mengacu pada Yesus, sang Mesias, tokoh utama dari pasal 19 kitab Wahyu. Bagian terakhir yaitu harapan, terlihat dari penggunaan imageri ini di kitab Wahyu. Imageri perjamuan makan yang diadakan di Sion seperti yang ditulis dalam Yesaya 25:6, 9, adalah imageri yang menggambarkan harapan bertahtanya sang mesias. Harapan adanya keadilan yang memberikan keadilan pada yang lemah dan miskin serta para pengungsi. Imageri ini juga digunakan di Wahyu 19:7. Jadi ke dua ayat itu, baik Yesaya 25:6 dan 9 dan Wahyu 19:7 dapat disebut sejajar karena penggunaan imageri yang sama.

157 J. Paul Tanner, “The 'Marriage Supper Of The Lamb' In Rev 19:6-10 Implications For The Judgment Seat Of Christ," Trinity Journal 26, no. 1 (2005). 


\section{Imageri Perjamuan Makan dan Keramahtamahan di Mazmur 23:5a}

Mazmur 23:5a menampilkan imageri yang berbeda dengan ayat 1-4 karena menempatkan berkat eskatologis yaitu perjamuan makan (menyediakan hidangan) Dalam budaya Perjanjian Lama, menyediakan hidangan atau mengadakan perjamuan makan bagi tamu adalah satu bentuk keramahtamahan. Bukan hanya Abram, di PL terdapat contoh lain tentang keramahtahaman yang diwujudkan dengan menyediakan hidangan: Lot (Kej.19:3), seorang Lewi (Hak. 19:21), Elia (2 Raj. 4:8). Untuk kepentingan tulisan ini hanya dua contoh pertama yang akan diperhatikan hubungannya dengan keramahtamahan di Mazmur 23:5a.

Seperti penjelasan imageri perjamuan makan di bagian sebelumnya yang dipahami dari penggunaannya di Alkitab, demikian juga perjamuan makan sebagai wujud keramahtamahan di Mazmur 23:5a ini harus dipahami dengan memperhatikan pemahaman orang pada saat itu tentang cara menunjukkan keramahtamahan.

Perhatikan narasi Lot dan seorang Lewi, dua narasi itu mempunyai kemiripan. ${ }^{158}$

\begin{tabular}{|c|c|c|}
\hline Konsep & Narasi tentang Lot (Kej. 19) & Narasi tentang seorang Lewi (Hak. 19) \\
\hline Setting & $\begin{array}{l}\text { Dua orang asing mengunjungi Lot } \\
\text { (ay.2-3) }\end{array}$ & $\begin{array}{l}\text { Menginap sebagai orang asing (ay. 18- } \\
\text { 20) }\end{array}$ \\
\hline $\begin{array}{l}\text { Jamuan Makan } \\
\text { yang diberikan } \\
\text { tuan rumah }\end{array}$ & $\begin{array}{l}\text { Tetapi karena ia (Lot) sangat } \\
\text { mendesak mereka, singgahlah } \\
\text { mereka dan masuk ke dalam } \\
\text { rumahnya, kemudian ia } \\
\text { menyediakan hidangan bagi } \\
\text { mereka, ia membakar roti yang tidak } \\
\text { beragi, lalu mereka makan. }\end{array}$ & $\begin{array}{l}\text { Sesudah itu dibawanyalah dia masuk ke } \\
\text { rumahnya, lalu keledai-keledai } \\
\text { diberinya makan; maka merekapun } \\
\text { membasuh kaki, makan dan minum }\end{array}$ \\
\hline \multirow[t]{2}{*}{ Masalah } & Orang-Orang mengepung rumah Lot & $\begin{array}{l}\text { Penduduk kota mengepung rumah } \\
\text { orang Gibea itu. }\end{array}$ \\
\hline & $\begin{array}{l}\text { Penduduk kota meminta supaya Lot } \\
\text { membawa tamunya keluar supaya } \\
\text { mereka dapat memakai mereka }\end{array}$ & $\begin{array}{l}\text { Penduduk kota meminta orang Gibea } \\
\text { itu membawa keluar tamunya supaya } \\
\text { mereka dapat memakainya. }\end{array}$ \\
\hline $\begin{array}{l}\text { Tindakan tuan } \\
\text { rumah }\end{array}$ & $\begin{array}{l}\text { Lot keluar menemui mereka dan } \\
\text { menutup pintu }\end{array}$ & $\begin{array}{l}\text { Pemilik rumah itu keluar dan menemui } \\
\text { mereka }\end{array}$ \\
\hline $\begin{array}{l}\text { Perkataan tuan } \\
\text { rumah pada } \\
\text { orang-orang } \\
\text { jahat }\end{array}$ & $\begin{array}{l}\text { dan ia berkata: Saudara-saudaraku, } \\
\text { janganlah kiranya berbuat jahat. } \\
\text { Kamu tahu, aku mempunyai dua } \\
\text { orang anak perempuan yang belum } \\
\text { pernah dijamah laki-laki, baiklah } \\
\text { mereka kubawa ke luar kepadamu; } \\
\text { perbuatlah kepada mereka seperti }\end{array}$ & $\begin{array}{l}\text { Saudara-saudaraku, janganlah kiranya } \\
\text { berbuat jahat; karena orang ini telah } \\
\text { masuk ke rumahku, janganlah kamu } \\
\text { berbuat noda. Tetapi ada anakku } \\
\text { perempuan, yang masih perawan, dan } \\
\text { juga gundik orang itu, baiklah kubawa } \\
\text { keduanya ke luar; perkosalah mereka }\end{array}$ \\
\hline
\end{tabular}

${ }^{158}$ Saat ini cukuplah untuk melihat kemiripan kedua narasi itu dalam Bahasa Indonesia, karena dengan menggunakannya tujuan tulisan ini sudah tercapai. Hasil yang lebih menarik akan diperoleh jika menelusuri kesamaan kata-kata yang digunakan di dua narasi ini. 
yang kamu pandang baik; hanya jangan kamu apa-apakan orangorang ini. dan perbuatlah dengan mereka apa yang kamu pandang baik, tetapi terhadap orang ini janganlah kamu berbuat noda.

Dua narasi ini sangat mirip bahkan sampai urut-urutan peristiwanyapun mirip. Motif keramahan tuan rumah sangat jelas terlihat di dua narasi ini. Kedua tuan rumah itu mendesak tamu mereka untuk datang dan menjamu dengan makanan dan minuman. Bahkan ketika penduduk kota mengancam untuk memakai mereka, ke dua tuan rumah itu rela mengorbankan anak perempuan ${ }^{159}$ mereka demi memastikan keamanan tamunya yang sedang menikmati makanan yang disediakannya.

Pengetahuan tentang keramahtamahan tuan rumah terhadap tamunya yang terlihat dalam dua narasi di atas akan sangat menolong ketika seseorang membaca Maz. 23:5a, "Engkau menyediakan hidangan bagiku, di hadapan lawanku." Daud pasti mengetahui tata krama dan keramahtamahan pada waktu itu. Dalam pengetahuan itulah dia menggambarkan Tuhan, sebagai tuan rumah yang baik, yang akan membiarkannya menyantap hidangan di hadapan setiap lawannya. ${ }^{160}$ Tuhan, gembala yang baik itu, juga akan menyediakan perjamuan makan baginya dan memastikan dia ada dalam keadaan aman, sehingga dapat menyantap setiap hidangan yang sudah disediakan. Bullock, mengutip Goldingay, menyebutkan dengan singkat bahwa ay. 5a adalah sebuah jamuan makan tindakan yang penuh anugerah. Tafsiran ini mengacu juga pada Ams. 9:1-2, di dua ayat itu disebutkan bahwa hikmat (yang dalam kitab Amsal disebutkan juga terlibat dalam penciptaan) memotong ternak sembebelihannya, mencampur anggurnya dan menyediakan hidangannya. Itulah yang sebenarnya menjadi keyakinan Daud tentang kebaikan eskatologis dari orang-orang yang menjadikan Tuhan gembala bagi hidupnya.

${ }^{159}$ Budaya pada saat itu tentu berbeda dengan budaya saat ini dalam hal gender. Budaya patriarkhal sangat kuat pada jaman itu, walaupun di Alkitab terdapat banyak tokoh wanita yang mendapatkan tempat terhormat. Penulis Alkitab mencatat dua peristiwa ini apa adanya, karena memang pada saat itu demikianlah budayanya.

${ }^{160}$ Bullock, mengutip Goldingay, menyebutkan dengan singkat bahwa ay. 5a adalah sebuah jamuan makan tindakan yang penuh anugerah. Tafsiran ini mengacu juga pada Ams. 9:1-2, di dua ayat itu disebutkan bahwa hikmat (yang dalam kitab Amsal disebutkan juga terlibat dalam penciptaan) memotong ternak sembebelihannya, mencampur anggurnya dan menyediakan hidangannya. Penafsiran ini tentu dapat melengkapi pembahasan di atas. C. Hassell Bullock, Psalm, vol. Volume 1, Psalm 1-72, Teach the Text Commentary Series (Grand Rapids, Michigan: Baker Books, 2015). 


\section{Imageri Perjamuan Makan dan Harapan Eskatologis Pentakosta Klasik}

Masalah eskatologi memang selalu menjadi bahasan yang menarik di kalangan Pentakosta. Sejak awal mulanya, topik ini sudah mewarnai pemberitaan para penginjil Pentakosta mula-mula. Koran Apostolic Faith edisi pertama mencatat kesaksian panggilan Anna Hall yang sarat dengan nuansa eskatologi. Dia mendengar suara yang mengatakan bahwa Jesus is coming soon, oleh sebab itu go forward in my name, preach the Gospel of the kingdom for the King's business demand haste. ${ }^{161}$ Pentecostal Evangel, sebuah majalah mingguan yang diterbitkan oleh Assembly of God USA, pada bulan Maret tahun 1914, mencatat sebuah artikel yang berisi kemendesakan kedatangan Tuhan. Di dalamnya dicatat pula sebuah perkiraan tentang kapan Yesus akan datang.

In a letter which appears on page eight of this issue, the end of the age is mentioned as coming in 19_. We left the two-last number off purposely as we do not consider it best to set positive dates for the coming of Christ. The number, however was 33. Others have had visions and have seen 1914, 1917 etc.... These figures are just vague enough to cause God's people to watch, for the know in what hour the lord shall come.... But one thing is certain and that is that the Lord is coming and coming soon. Let Him find us ready when He comes, busy about the work He has called us to do. ${ }^{162}$

Tidak diragukan, jika ditelusuri lebih jauh, akan ditemukan banyak catatan dan pemberitaan yang menunjukkan hubungan antara Pentakosta dengan eskatologi. ${ }^{163}$

Dari sekian banyak harapan eskatologis yang tertuang dalam tulisan-tulisan awal tentang gerakan pentakosta, imageri perjamuan makan juga digunakan untuk menggambarkan harapan eskatologis itu. Perhatikan tulisan McQueen berikut ini:

The most frequent and consistently applied biblical metaphor used in reference to the Second Coming of Jesus in The Apostolic Faith was that of the bride of Christ viewed in the

161 “Jesus Is Coming," Apostolic Faith, September 1906, Vol. 1, No. 1 edition.

162 Fountain Colo, “Christian Evangel," The Christian Evangel, March 28, 1914, Vol. 2. No 13. edition.

163 Kini, pentakosta berkembang pesat, dan pembahasan tentangnya meluas. Ketika berbicara tentang pentakosta, seseorang dapat menghubungkannya dengan banyak bidang, dan melihatnya dari banyak sudut pandang. Jika dihubungkan dengan letak geografis, seperti Afrika, Eropa, Amerika Selatan, Asia dan lain-lain, maka beragam warna dan kekhasan pentakosta akan muncul. Demikian juga jika pembahasan pentakosta dihubungkan dengan antropologi, teologi pembebasan, gender, dan banyak bidang lainnya, akan ditemukan banyak hal baru. Dalam buku berikut ini terdapat pendahuluan yang memadai tentang perkembangan pentakosta mulai dari kemunculannya sampai perkembangannya saat ini. Allan Heaton Anderson, An Introduction to Pentecostalism: Global Charismatic Christianity (Cambridge University Press, 2013). 
contexts of the parable of the ten virgins (Matt 25:1-13) and the marriage supper of the Lamb (Rev 19: 9). ${ }^{164}$

Perhatikan juga tulisan dalam koran Apostolic Faith berikut ini:

I said "Surely this is a messenger from the holy country." The voice answered. "Yes and I have come to tell you that Jesus is coming. Go forward in My name, preach the GOspel of the Kindom, for the King's business demands haste. My People have only time to get on the beautiful garments, and prepare for the wedding supper in the Heavens." 165

Perjamuan makan dipahami oleh orang-orang pentakosta klasik sebagai sebuah harapan di masa yang akan datang yang akan dinikmati oleh setiap orang yang dapat mempersiapkan dirinya dengan "pakaian pesta" untuk menyambut kedatangan Sang Mempelai.

\section{Membaca Mazmur 23:5a}

\section{dari Sudut Pandang Harapan Eskatologis Pentakosta Klasik}

Adalah wajar jika dari sekian banyak imageri perjamuan makan di Perjanjian Lama dan Perjanjian Baru, para penulis dan tokoh pentakosta klasik memilih untuk menggunakan imageri yang terdapat dalam Wahyu. Alasannya adalah karena kitab Wahyu itu sendiri adalah kitab yang identik dengan akhir jaman, kitab yang berbicara tentang harapan kedatangan kembali Sang Juru Selamat, dan kemenangan mutlak setiap orang percaya serta berkumpulnya semua orang percaya dengan Sang Raja di atas segala raja. Kitab Mazmur tidak akan dengan mudah dipilih untuk berbicara tentang harapan eskatologis karena dalam Maz. 23 hanya akan dimunculkan gambaran Tuhan sebagai gembala yang baik yang menolong setiap dombanya.

Maz.23:5a sebenarnya dapat digunakan untuk menggambarkan harapan eskatologis seperti Wah. 19:9. Alasannya adalah bahwa Wah. 19:9 berbicara berkumpulnya orang-orang percaya dalam sebuah pesta jamuan makan, dan ini terjadi setelah Babilon dihancurkan. Perhatikan juga kemiripan yang ada di Maz. 23:5a. Maz. 23:5a dilatar belakangi oleh pemahaman bahwa sang tuan rumah akan menyediakan

${ }^{164}$ Larry McQueen, "Early Pentecostal Eschatology in the Light of The Apostolic Faith, 1906-1908," in Perspectives in Pentecostal Eschatologies: World Without End, Kindle Edition (Eugene, Oregon, 2009), 14445.

165 “Jesus Is Coming." Apostolic Faith 1.1 (September 1906) 
makanan dan tidak membiarkan setiap orang-orang jahat menyentuh tamunya yang sedang makan.

Jika memperhatikan dengan saksama maka mazmur 23:5 menggunakan paralelisme sederhana yang mengulang subyek:

Engkau menyediakan hidangan bagiku di hadapan lawanku Engkau mengurapi aku dengan minyak

Lazimnya paralelisme seperti ini hanya menggunakan satu subyek saja,subyek di kalimat,166 Namun berbeda yang terdapat dalam Mazmur 23:5 karena penggulangan subyek oleh Daud memberikan penekanan pada Tuhan yang melakukan dua aktivitas kepadanya. Dari kedua aktivitas yang sedang Daud ungkapkan dalam 23:5a ini satunya telah tergenapi, sedangkan lainnya masih merupakan harapan yang belum terjadi. Aktivitas yang telah tergenapi adalah aktivitas kedua, "Tuhan mengurapi Daud dengan minyak." Hal ini terjadi dalam I Sam. 16:13 ketika Samuel mengurapinya dengan minyak untuk menjadi raja. Sementara itu aktivitas pertama yang disebutkan Daud tentang Tuhan yang merupakan subyek utama di dalamnya , "Engkau menyediakan hidangan bagiku di hadapan lawanku" masih belum terjadi.

Daud sering mengutarakan harapan dalam dirinya dengan menggunakan berbagai imageri, contohnya "seperti penjaga mengharap fajar pagi," dan "seperti rusa merindukan air." Imageri seperti ini biasanya hanya dihubungkan dengan harapan yang sementara saja yaitu harapan untuk lepas dari genggaman musuh. Namun sebenarnya, harapan-harapan itu dapat dipahami juga sebagai harapan untuk mendapatkan kemenangan sempurna bersama dengan Tuhan di masa yang akan datang. Harapan seperti ini mencerminkan adanya kesadaran religius yang tidak hanya mengharapkan kebebasan dari masalah duniawi semata, tetapi hubungan dengan Tuhan. Vos mengatakan:

we encounter the ideas of peace, universalism, paradise restored, the dwelling of Jehovah's presence in the land, the vision of God, the enjoyment of glory, light, satisfaction of all

166 Kedua ditiadakan, perhatikan kutipan dari Maz. 102:2

Ya Tuhan, lepaskanlah aku dari pada bibir dusta

(Ya Tuhan, lepaskanlah aku) dari pada lidah penipu

Subyek dan kata kerja di kalimat ke dua ditiadakan karena sudah disebutkan di kalimat pertama. 
wants, the outlook beyond death towards an uninterrupted contact with God and a esurrection. Only in the Psalms all this is suffused with the genial warmth of religious feeling. ${ }^{167}$

Jadi, jika Maz. 23:5a dapat dipahami sebagai harapan yang belum terjadi, maka harapan yang ada di ayat ini dapat disamakan dengan harapan yang terdapat di Wahyu 19:9.

Lebih dari pada itu, McQueen menjelaskan bahwa untuk dapat hadir dalam perjamuan makan seseorang harus baptized in the Spirit. 168 Dia mengutip penjelasan Seymour yang terdapat dalam Apostolic Faith edisi Januari 1907. Seymour mengatakan:

Dearly beloved, the only people that will meet our Lord and Savior Jesus Christ and go with Him into the marriage supper of the Lamb, are the wise virgins - not only saved and sanctified, with pure and clean hearts, but having the baptism with the Holy Ghost. ${ }^{169}$

Dengan demikian dapat juga dikatakan bahwa hanya orang-orang yang baptized in the spirit yang akan menerima hidangan dan perlindungan di hadapan lawan-lawan mereka.

Pada akhirnya menarik untuk diperhatikan bahwa tidak semua orang akan dapat menikmati hidangan yang disediakan oleh Tuhan di hadapan lawan-lawannya. Karena tindakan Allah menyediakan hidangan itu memiliki dua sisi: berkat dan kutuk. Theopilus dari Alexandria mengatakan bahwa the table is a blessing for us but punishment for them. ${ }^{170}$

\section{Daftar Pustaka}

Anderson, Allan Heaton. An Introduction to Pentecostalism: Global Charismatic Christianity. Cambridge University Press, 2013.

\footnotetext{
${ }^{167}$ Geerhardus Vos, "Eschatology of the Psalter,” n.d., 43.

${ }^{168}$ McQueen, 144-145.

${ }^{169}$ Ibid.

${ }^{170}$ Craig A. Blaising and Carmen S. Hardin, Ancient Christian Commentary on Scripture: Psalm 1-50,
} ed. Thomas C. Oden, Epub Edition, vol. VII (Downers Grove, IL: IVP Academic, 1998). 
Blaising, Craig A., and Carmen S. Hardin. Ancient Christian Commentary on Scripture: Psalm 1-50. Edited by Thomas C. Oden. Epub Edition. Vol. VII. Downers Grove, IL: IVP Academic, 1998.

Bullock, C. Hassell. Psalm. Vol. Volume 1, Psalm 1-72. Teach the Text Commentary Series. Grand Rapids, Michigan: Baker Books, 2015.

Bush, Fredric, W. Word Biblical Commentary: Ruth, Esther. Electronic Edition. Dallas: Word, Incorporated, 2002.

Colo, Fountain. “Christian Evangel.” The Christian Evangel. March 28, 1914, Vol. 2. No 13. edition.

“Jesus Is Coming." Apostolic Faith. September 1906, Vol. 1, No. 1 edition.

Lindsey, F. Duane. “Isaiah's Songs of the Servant Part 4: The Career of the Servant in Isaiah 52:13-53:12." Bibliotheca Sacra 139, no. 556 (1982).

McQueen, Larry. "Early Pentecostal Eschatology in the Light of The Apostolic Faith, 1906-1908." In Perspectives in Pentecostal Eschatologies: World Without End, Kindle Edition., 144-45. Eugene, Oregon, 2009.

Nolland, John. Word Biblical Commentary : Luke 9:21-18:34. World Biblical Commentary 35B. Dallas: Word, Incorporated, n.d.

Ryken, Leland, Jim Wilhoit, Tremper Longman, Colin Duriez, Douglas Penney, and Daniel G Reid. Dictionary of BIblical Imagery. Electronic Edition. Downers Grove, IL: InterVarsity Press, 2000.

Tanner, J. Paul. “The 'Marriage Supper Of The Lamb’ In Rev 19:6-10 Implications For The Judgment Seat Of Christ." Trinity Journal 26, no. 1 (2005).

Vos, Geerhardus. "Eschatology of the Psalter," n.d., 43.

Tentang Penulis

Penulis adalah staf pengajar di STT Berea, Salatiga. Kini sedang menempuh studi doktoral teologi di Fachhochchule für Interkulturelle Theologie di Hermansburg, Jerman. 